\title{
MICROWAVE IRRADIATION SYSTEM FOR A RAPID SYNTHESIS OF NON-TOXIC METALLIC COPPER NANOPARTICLES FROM GREEN TEA
}

\author{
Israt JAHAN* ${ }^{*}$ Ibrahim ISILDAK \\ Department of Bioengineering, Y1ldı Technical University, TURKEY
}

Cite this article as:

Jahan I., Isildak I. 2020. Microwave irradiation system for a rapid synthesis of non-toxic metallic copper nanoparticles from green tea. Trakya Univ J Nat Sci, 21(2): 79-86, DOI: 10.23902/trkjnat.731692

Edited by:

Yeşim Săg Açıkel

*Corresponding Author:

Israt Jahan

sonia.israt@yahoo.com

\section{ORCID ID:}

orcid.org/0000-0003-4166-1617

Key words:

Green tea

Microwave-assisted green

synthesis

Bioreduction

Non-toxic metallic CuNPs

\begin{abstract}
This paper presents a rapid protocol of microwave-assisted green synthesis of nonoxidized metallic copper nanoparticles (CuNPs) using green tea (Camellia sinensis (L.) Kuntze) extract. Following the successful biosynthesis, characterization techniques such as UV-vis spectroscopy, Fourier transform infrared spectroscopy (FTIR), Scanning electron microscopy (SEM) associated with Energy Dispersive X-ray analysis (EDX), X-ray Diffraction (XRD) and Zeta analysis were employed to confirm the presence of metallic CuNPs and reveal their morphology. UV-vis spectrum of fabricated CuNPs indicated its characteristic maximum absorbance at $570 \mathrm{~nm}$. Synthesized CuNPs were found to be round to globular in shape, with average size of $45.30 \mathrm{~nm}$, and showed excellent stability without any aggregation for several months. EDX graph confirmed the highest amount of copper atoms (77.96\%) along with carbon and oxygen with the percentage of $17.17 \%$ and $4.87 \%$, respectively. The non-toxic nature of the phytosynthesized CuNPs was further established by using healthy mouse fibroblast L929 cell line, which showed their potentiality for biological research and many other applications.
\end{abstract}

Özet: $\mathrm{Bu}$ makale, yeşil çay (Camellia sinensis (L.) Kuntze) ekstraktsiyonu kullanılarak oksitlenmemiş metalik bakır nanopartiküllerinin (CuNPs) mikrodalga destekli yeşil sentezinin hızlı bir protokolünü sunmaktadır. Başarılı biyosentezi tamamladıkten sonra, bakır nanopartiküllerin varlığını doğrulamak ve morfolojilerini ortaya çıkarmak için UV-vis absorpsiyon spektroskopi, Fourier Dönüşümlü Kızıl Ötesi Spektrometresi (FTIR), Enerji dağıtıcı X-1şını analizi (EDX) ile ilişkili Taramalı elektron mikroskobu (SEM), X-ışını Kırınımı (XRD) ve Zeta analiz gibi karakterizasyon teknikleri uygulanılmıştır. Üretilmiş CuNP'lerin UV-vis spektrumu, $570 \mathrm{~nm}$ 'de karakteristik maksimum absorbansını göstermiştir. Sentezlenen CuNP'lerin, ortalama 45,30 nm büyüklüğünde yuvarlaktan küre şeklinde, birkaç ay boyunca herhangi bir agregasyon olmadan mükemmel stabilite sergilediği bulunmuştur. EDX grafiği, karbon ve oksijenın sırasıyla $\% 17,17$ ve $\% 4,87^{\prime}$ lik oranlarla birlikte en yüksek miktarda bakır atomunu $(\% 77,96)$ doğrulanmıștır. Son olarak, sağlıklı fare fibroblast hücreleri (L929 hücre çizgisi) üzerindeki biyosentezlenmiş bu CuNP'lerin non-toksik özelliği doğrulanmıştır ve bu durum, bunların biyolojik araştırmaların yanı sıra geniş kapsamlı uygulamalarda potansiyellerini de göstermektedir.

\section{Introduction}

Noble metallic nanoparticles (NPs) have been attracted by the scientists of different fields, as a result of their unique magnetic, optical, catalytic, and electrical properties, and wide range multidisciplinary applicability (Tsuji et al. 2005). Concerning eco-safety, it is necessary to expand environmental friendly approaches without using toxic and hazardous chemicals. Use of plant-based extractions for the synthesis of metallic nanoparticles is advantageous, which is convenient, cost effective and non-hazardous for the environment (Jha et al. 2009, Annamalai et al. 2011). Moreover, synthesis of nontoxic metallic nanoparticles is also necessary since these particles are utilized extensively in the areas of human contact.
Copper nanoparticles have earned more importance because of their historical usages as coloring agents, as well as their broad-spectrum bioactivity and biomedical application in contemporary time. In recent times, they are taken as one of the most applied disinfectants for drinking-water purification due to their strong antimicrobial potential (Ruparelia et al. 2008). Besides, catalytic activities, high thermal and electrical conductivities of CuNPs facilitate their suitability for developing different biosensors and electrochemical sensors (Wei et al. 2010). Moreover, copper is most abundant naturally occurring metallic element; therefore, this metal is cheaper than other metals, i.e. platinum, gold and silver; therefore, CuNPs synthesis is 
more profitable than other metallic nanoparticles. Nonetheless, the biggest problems for synthesizing stable CuNPs are their susceptibility to aggregation and tendency to oxidize easily during NPs production (Lee et al. 2013, Dang et al. 2011). For this reason, a rapid green synthesis method with suitable plant extract for the production of non-oxidized metallic copper nanoparticles is able to resolve this problem. Aiming this, plant mediated synthesis with microwave irradiation could be the fast and facile option for copper nanoparticle production. Microwave irradiation provides a fast and homogeneous heating system which confirms consistent nucleation and growth of nanoparticles in the reaction medium within a short period of time, increase the rate of capping by plant extracts, and speed up the stabilization process of NPs; and thereby, reduce oxidation and aggregation rate of CuNPs (Joseph \& Mathew 2015, Nasrollahzadeh \& Sajadi 2015). Previous studies have suggested that the microwave-assisted synthesis scheme is the effective approach for producing highly stable metallic CuNPs (Yallappa et al. 2013, Nasrollahzadeh \& Sajadi 2015, Sreeju et al. 2016, Tanghatari et al. 2017). For instance, microwave irradiation was utilized in a study to synthesize zero valent metallic copper $(\mathrm{Cu} 0)$ nanoparticles from Terminalia arjuna (Roxb.) Wight \& Arn. bark extract (Yallappa et al. 2013). Similarly, highly stable metallic copper nanoparticles (CuNPs) were synthesized by using Psidium guajava L. leaf extract and hydrazine through microwave-assisted onepot method (Sreeju et al. 2016). On the other hand, metallic non-oxidized CuNPs were successful synthesized separately from both potato starch and polyvinylpyrrolidone (PVP) after using microwave heating system (Tanghatari et al. 2017).

Based on the above mentioned reasons, this study was designed to establish a suitable rapid and facile green synthesis of metallic copper nanoparticles (CuNPs) by using green tea (Camellia sinensis (L.) Kuntze) extract under microwave irradiation. Choosing green tea for synthesizing CuNPs in this study was due to the fact that its extract is rich in different biologically active polyphenols, bioflavonoids, alkaloids, caffeine, volatile compounds, amino acids, glucides, proteins, reducing sugars, etc., which could be very effective reducers and stabilizers during the synthesis process (Reto et al. 2007). Previously, green tea leaves extract has been utilized for synthesizing copper oxide (Sutradhar et al. 2014), iron (Gottimukkala et al. 2017, Lourenço et al. 2019), zinc oxide (Irshad et al. 2018) and silver (Rolim et al. 2019) nanoparticles; and different bioactive polyphenols of the green tea extract were found to be common functional compounds that worked as reducing agent as well as capping agent for synthesizing these NPs.

Aiming for a rapid and simplistic synthesis using green tea extract therefore, two very basic parameters i.e., time and temperature of the microwave system were chosen for the production of metallic non-oxidized CuNPs. Afterwards following the successful biosynthesis, various characterization techniques were employed to confirm the presence of CuNPs as well as reveal their shape, size and other morphologic features. Furthermore, cytotoxic effect of phytosynthesized copper nanoparticles was also examined to ensure their safe usages of nanobased researches and application in biological science.

\section{Materials and Methods}

Plant Extract Preparation and Fabrication of $\mathrm{Cu}$ Nanoparticles

In this study, copper (II) sulfate pentahydrate $\left(\mathrm{CuSO}_{4} .5 \mathrm{H}_{2} \mathrm{O}\right)$ and other chemicals needed were analytical grade, which were acquired from SigmaAldrich (St. Louis, MO, USA). Instruments were properly dried and autoclaved before use. $10 \mathrm{gm}$ dried green tea leaves were taken into $250 \mathrm{ml}$ Erlenmeyer flask with 100 $\mathrm{ml}$ ultra-purified deionized water, place onto as electric heater (lab-grade) at $80^{\circ} \mathrm{C}$ for $20 \mathrm{~min}$ with continuous rousing using a magnetic stirring bar. Afterwards, Whatman No. 1 filter paper was employed for removing debris from the extract solution was then filtered using and kept at $4^{\circ} \mathrm{C}$.

Different ratios of plant extract and salt solution were used to determine the optimum parameters for copper nanoparticle synthesis, and the successful synthesis was obtained when $50 \mathrm{ml}$ fresh green tea extract and $50 \mathrm{ml} 1$ $\mathrm{mM} \mathrm{CuSO}_{4} .5 \mathrm{H}_{2} \mathrm{O}$ solutions were mixed together and then, heated in the microwave for 2 minutes at $700 \mathrm{~W}$ with continuous stirring by magnetic stirrers. Afterward, $5 \mathrm{ml}$ L-ascorbic acid (10\%) solution was mixed within the synthesis medium, and then again, placed into microwave for $15 \mathrm{~min}$ at $700 \mathrm{~W}$, which provided constant homogenous heating of $160-170^{\circ} \mathrm{C}$ (power setting: $\mathrm{P} 80$ ). L-ascorbic acid at very low concentration was used as an additional precursor for preventing the oxidation of biosynthesizing nanoparticles especially after postsynthesis phase until purification process since metallic copper nanoparticles are very sensitive to aqueous solution, and tend to oxidized easily (Cheng et al. 2006, Suresh et al. 2014). After forming a dark blackish brown colloid inside the synthesis medium, Whatman Grade No. 5 filter paper with $2.5 \mu \mathrm{m}$ pore size was used to eliminate large discarded particles from the sample solutions; then centrifuged 3-4 times at $5000 \mathrm{rpm}$ for 15 minutes at $4^{\circ} \mathrm{C}$. Finally, the purified precipitate was dried under vacuum condition; and powdered CuNPs stocked in a dark colored vial, which was stocked up at $4^{\circ} \mathrm{C}$ further experiments.

\section{Characterization of Synthesized CuNPs}

Shimadzu UV-1700 spectrophotometer was used for revealing the optical property of synthesized copper NPs. Using UV-vis quartz cell, powdered nanoparticles suspended in deionized water was used to collect spectral peaks at the rage of 200-800 nm wavelengths where ultrapurified $\mathrm{H}_{2} \mathrm{O}$ was taken as blank. Using FT/ IR-6300 (JASCO, Tokyo, Japan) spectrometer, potassium bromide (KBr) pellet (FTIR grade) method was applied to read IR 
spectra in the range of $4000-400 \mathrm{~cm}^{-1}$. XRD patterns with a step size of 0.02 was taken at the range of $2 \mathrm{~h}$ from $10^{\circ}$ to $90^{\circ}$ via X-ray diffraction (PANalytical Empyrean model) plan for recognizing crystalline nature of synthesized NPs; XRD graph was regenerated by the Origin 8.5 software. Scanning electron microscope adjusted with an EDX analyzer (SEM, SU-1510, Hitachi High-Technologies Corp., Tokyo, Japan) was used in order to identify morphological features and chemical composition of developed nanoparticles. Lastly, particle average size distribution, and potential value were determined using Zeta sizer (model name: Zetasizer nano ZS, Malvern Instruments Ltd., UK).

\section{Cytotoxicity Study of copper nanoparticles}

The cytotoxicity of biosynthesized CuNPs was evaluated on L929 mouse fibroblast cell lines. Using XTT assay [2,3-bis-(2-methoxy-4-nitro-5-sulfophenyl)-2Htetrazolium-5-carboxanilide] the percentage of viable cells in culture media was determined by observing optical intensity of these viable cells. For maintaining the culture of cell line, DMEM-F12 medium was utilized supplemented with $10 \%$ fetal bovine serum and penicillium-streptomycin, which was incubated at $37^{\circ} \mathrm{C}$ with $5 \% \mathrm{CO}_{2}$ air flow. After incubation, completely affluent cells were detached from the upper layers of the cell containing vessels using Trypsin. Afterward, by staining with Trypan blue, the viable cells were identified, and counted from the detached cultured cells. Prior to applying nanoparticle into cell medium, $1 \mathrm{~mL}$ medium was used to adjust the density of obtained viable cells to $10^{6}$. Aiming this adjustment, $100 \mu \mathrm{L}$ of cell suspension was plated in every well of sterile 96-well flat bottom microplate (BD, Biosciences) within a short period of time. Before incubating at $37^{\circ} \mathrm{C}$, the biosynthesized CuNPs was added to cultured cells with an increasing concentration $(0,0.1,0.25,0.5,1,2.5$ and $5 \mu \mathrm{g} / \mathrm{mL})$. After 24 hours of incubation, old medium was removed, and $100 \mu \mathrm{L}$ XTT solution (with $0.5 \mathrm{mg} / \mathrm{ml}$ DMEM, which was adjusted to Phenazine methosulfate $(7.5 \mu \mathrm{g} / \mathrm{mL}))$ containing $100 \mathrm{ml}$ fresh medium was added, and again incubated for 4 hours at the same temperature. Later on, a multiplate reader (model: Lab-Line Instruments, Melrose Park, IL, USA) at $450 \mathrm{~nm}$ was employed for measuring optical density (OD) of active viable cells from the suspension. Lastly, the cell viability was calculated in percentage (\%) following this equation (Sahu et al. 2016):
Cell viability $(\%)=\frac{\text { oD of specimen }}{\text { OD of control }} \times 100$

\section{Results}

In this study, the production of copper nanoparticles was accomplished using green tea (Camellia sinensis) extract, which played the vital role as reducer and stabilizer during the synthesis. Microwave-assisted synthesis system was adjusted based on temperature and time that provided high reaction kinetics in the reaction medium, and confirmed higher yield within a shorter period of time. Initially, the reduction of ionic copper to nanoparticles was confirmed by colloidal formation and color changing in the reaction medium (Fig. 1). Moreover, $\mathrm{UV}-\mathrm{Vis}$ absorbance of reaction medium after synthesis showed a peak of $\lambda \max$ at $570 \mathrm{~nm}$ (Fig. 2) indicating the presence of stabilized non-oxidized copper nanoparticles (Dang et al. 2011, Hassanien et al. 2018).

Furthermore, XRD analysis confirmed the crystalline nature of phytosynthesized copper nanoparticles. Fig. 3 exhibits the XRD pattern of biosynthesized CuNPs using green tea extract. Five strong diffraction peaks were centered at $43.47^{\circ}, 50.61^{\circ}, 74.32^{\circ}, 90.28^{\circ}$ and $95.40^{\circ}$, which according to the standard database of the JCPDS card no: 04-0784, correspond to the planes of (111), (200), (220), (311) and (222) corroborate the presence of facecentered cubic crystalline structures metallic nonoxidized copper particles (Otte 1961).

Fourier transform infrared (FTIR) spectroscopy of fabricated nanoparticles revealed diverse functional groups of biomolecules that coated with the nano-scaled particles by creating a layer, and worked as reducer and stabilizer agents during the development of CuNPs (Usha et al. 2017). Fig. 4 represents FTIR spectra of CuNPs phytosynthesized via green tree extract. Peaks were observed mainly at $3,560.89 \mathrm{~cm}^{-1}$ for $\mathrm{O}-\mathrm{H}$ stretching; 2,917.42 $\mathrm{cm}^{-1}$ for medium alkane C-H stretching; $1,631.24 \mathrm{~cm}^{-1}$ for strong alkene monosubstituted bond; $1,094.80 \mathrm{~cm}^{-1}$ for strong C-O stretching alcohol bond; $613.40 \mathrm{~cm}^{-1}$ for $-\mathrm{C}-\mathrm{X}$ bond (X=bromide) and $426.90 \mathrm{~cm}^{-1}$ for metal ligand bond. Considering the existence of these functional groups with biosynthesized nanoparticles, FTIR spectra therefore have confirmed that nanoparticles obtained in this study were enclosed, capped, and stabilized by some amino acid residues, proteins, reducing sugars, polyphenols, flavanones, and terpenoids available in green tea extract (Usha et al. 2017)

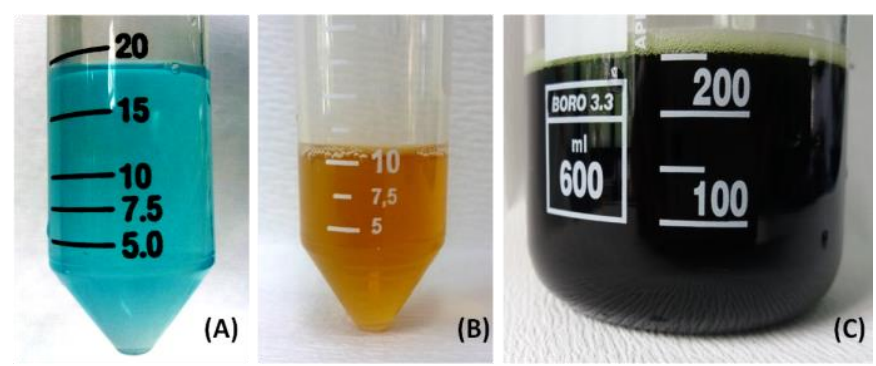

Fig. 1. (A) Copper (II) sulphate pentahydrate solution; (B) aqueous extract of green tea; and (C) color changed after the synthesis of copper nanoparticles. 


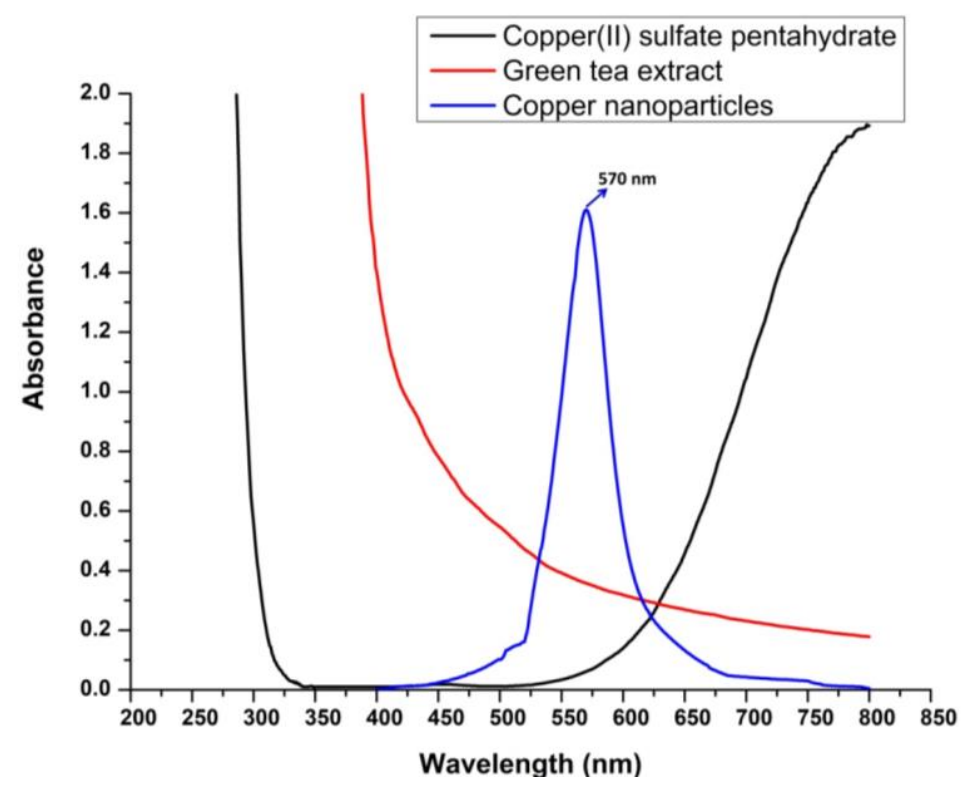

Fig. 2. UV-Vis spectra of biosynthesized copper nanoparticles using green tea extract.

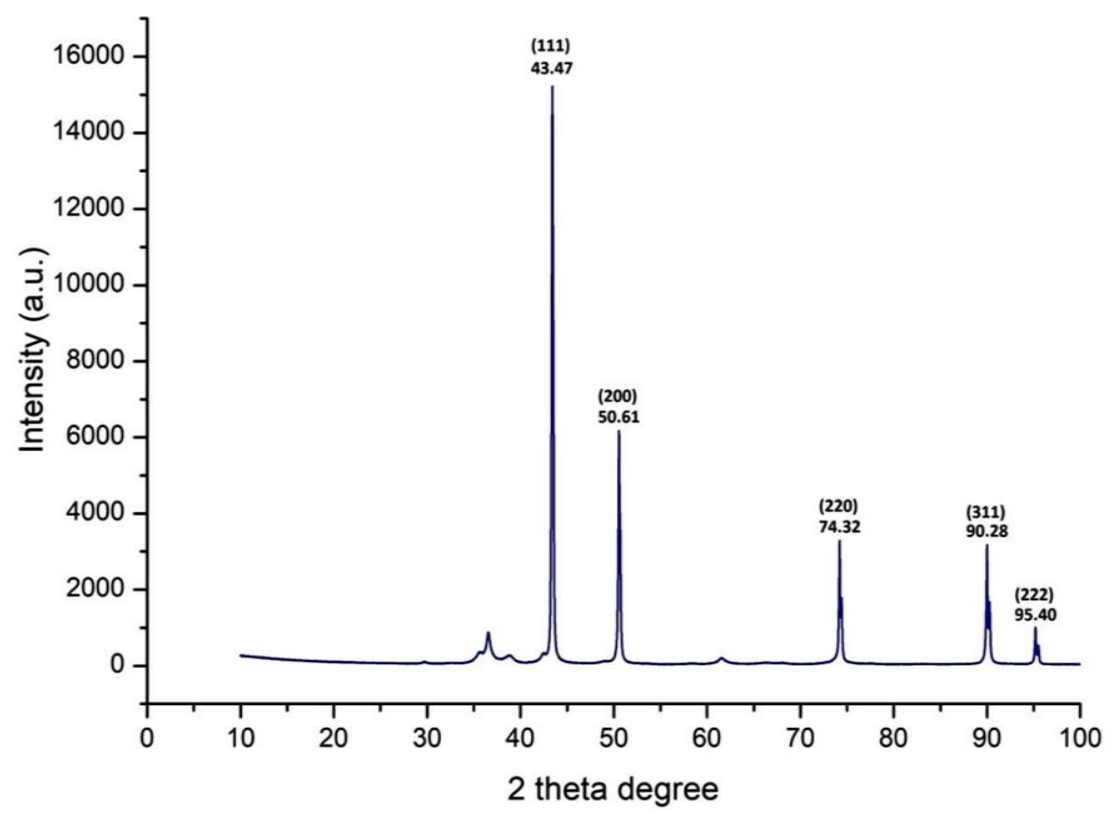

Fig. 3. XRD graph of phytosynthesized copper nanoparticles.

Scanning Electron Microscopy (SEM) at $5 \mu \mathrm{m}$ scale indicated the presence of round shaped copper nanoparticles (Fig. 5A) phytosynthesized from green tea extract. Besides, Energy-dispersive X-ray spectrometry (EDX) was employed to determine both qualitative and quantitative analysis of nanoparticles. EDX graph confirmed the highest amount of copper atoms (77.96\%) along with carbon and oxygen with the percentage of $17.17 \%$ and $4.87 \%$, respectively (Table 1 ). EDX study (Fig. 5B) also indicated the presence of non-oxidized metallic copper nanocrystals by giving characteristic peaks at 1, 8 and $9 \mathrm{keV}$ (Aziz 2017). Moreover, visible peaks of carbon and oxygen atoms were also followed the result of FTIR analysis.
Zetasizer provides the information about size distribution of nano-sized particles in terms of average particle diameter whereas the net surface charge of nanoparticles is measured by zeta potential value, which helps to understand the stability of the colloidal particles (Kaviya et al. 2011). The particle size distribution (Fig. 6A) and of potential value (Fig. 6B) the phytosynthesized CuNPs using green tea extract were revealed in Fig. 6. Particle dimension distribution by number has revealed the z-average of CuNPs as 45.30 $\mathrm{nm}$ with the mean potential value of $-19.0 \mathrm{mV}$. Higher negative value of NPs proved their better stability as a result of possible capping of the biomolecules available in green tea extract (Edison \& Sethuraman 2012). 


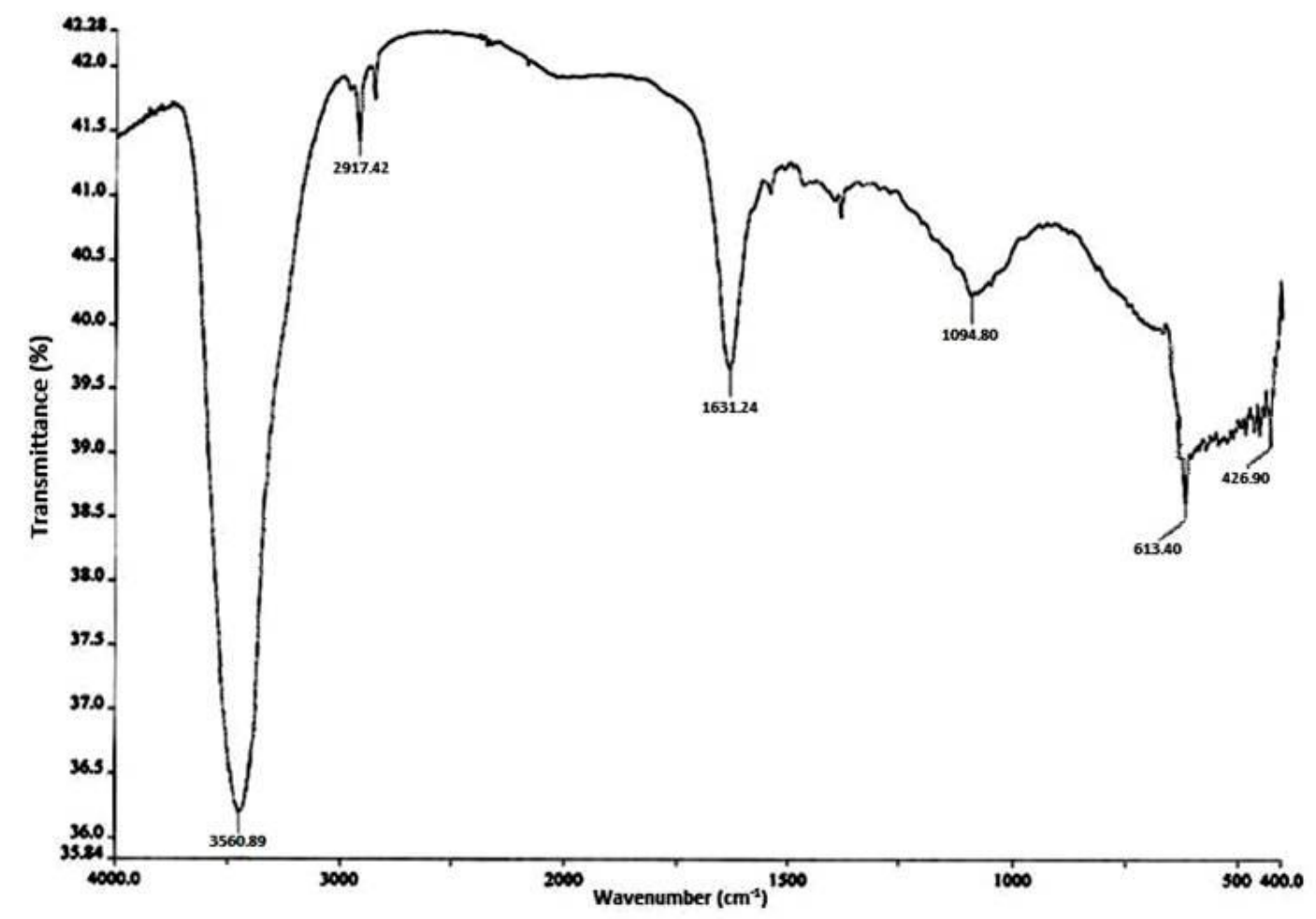

Fig. 4. IR spectra of biosynthesized copper nanoparticles using green tea extract.
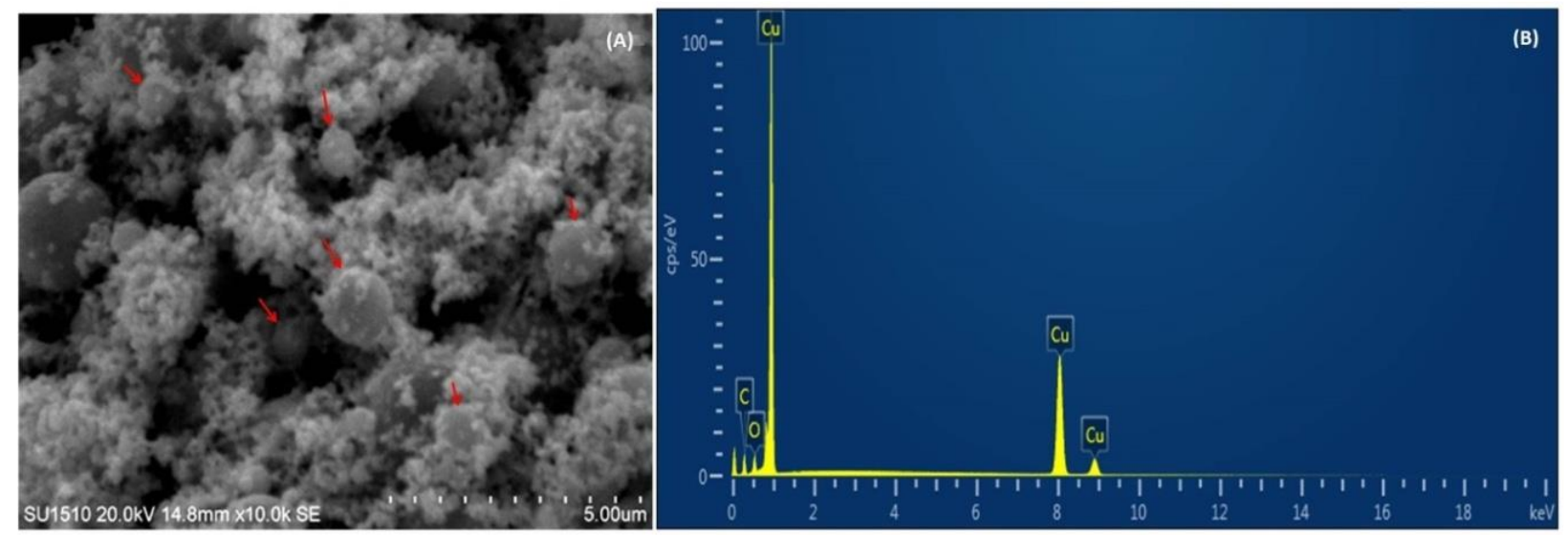

Fig. 5. (A) SEM image; (B) EDX graph of synthesized copper nanoparticles.
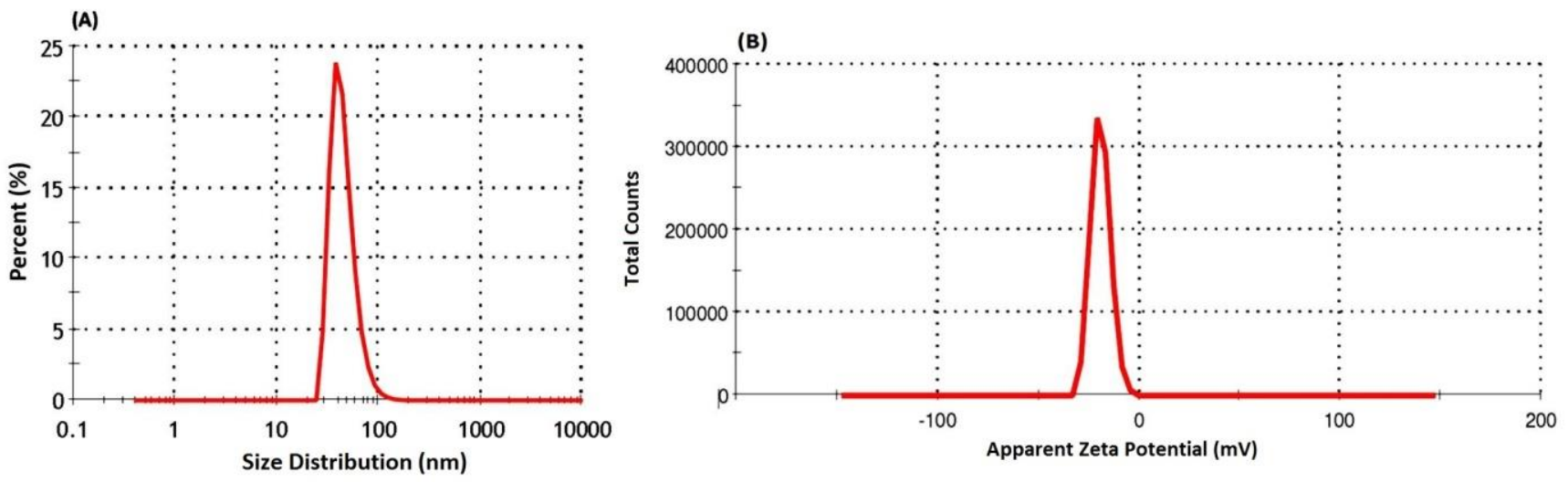

Fig. 6. (A) Particle size distribution; (B) zeta potential value of fabricated copper nanoparticles. 
Table 1. The weight percentage $(\%)$ of different elements present in biosynthesized CuNPs from green tea.

\begin{tabular}{cccc}
\hline \hline Element & Weight \% & Weight \% Sigma & Atomic \% \\
\hline \hline C & 17.17 & 0.23 & 48.29 \\
O & 4.87 & 0.09 & 10.27 \\
Cu & 77.96 & 0.23 & 41.44 \\
Total & 100.00 & & 100.00 \\
\hline \hline
\end{tabular}

To estimate biocompatibility of biosynthesized CuNPs, cytotoxic effect of nanoparticles was studied using healthy regular mouse fibroblasts cell line (L929). By applying XTT reagent, pigmentation rate of functional mitochondrial enzymes of viable cells after treated with different concentrated $(0,0.1,0.25,0.5,1,2.5$ and 5 $\mu \mathrm{g} / \mathrm{mL}$ ) copper nanoparticles was measured as the absorbance of optical density, which is directly proportional to the cell viability (Jahan et al. 2019). Fig. 7 showed the in vitro cytotoxic effects of copper nanoparticles phytosynthesized using green tea extract. Based on the absorbance values and by following the formula, the percentage of cell viability is more than $90 \%$ in each concentration of nanoparticles, which is considered as non-toxic (López-García et al. 2014).

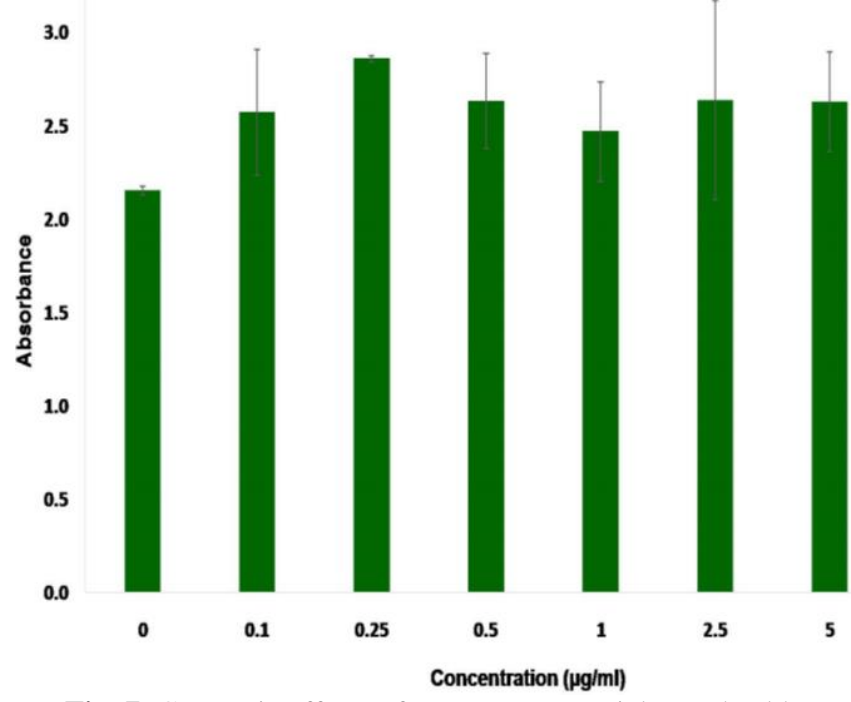

Fig. 7. Cytotoxic effects of copper nanoparticles on healthy regular mouse fibroblasts cell line (L929).

\section{Discussion}

A rapid and facile microwave-assisted green synthesis for fabricating non-oxidized metallic cooper nanoparticles (CuNPs) was established in this study. Regarding the development of non-oxidized metallic CuNPs, it is always challenging to synthesize CuNPs without any oxidation since metallic copper has a high tendency to oxidize easily during NPs production process if the synthesis process takes longer period of time (Lee et al. 2013). During the synthesis, microwave irradiation played as the driving force by providing a rapid and homogeneous heating system that sped up the synthesis process and accelerated the rate of capping by plant extracts which promoted a faster stabilization of biosynthesized CuNPs, and thus, produced non-oxidized copper without any aggression. Presence of non-oxidized CuNPs was further detected by UV-vis spectroscopy and XRD analysis.

Previous studies have utilized green tea and black tea extract as reducing and stabilization agents for metallic nanoparticle synthesis. But, they were applied mainly for synthesizing copper (II) oxide nanoparticles (CuONPs). For instance, tea leaf extract and copper nitrate at the ratio of 3:1 was subjected to microwave-irradiated heating for fabricating copper (II) oxide nanoparticles, which showed their characteristic absorption peak at $271 \mathrm{~nm}$ (Sutradhar et al. 2014). In an another study, copper nitrate and black tea powder extract (1:2 ratio) were used for synthesizing CuONPs which were attained after placing the reaction medium at $300^{\circ} \mathrm{C}$ for 3 hours (Mathew 2018). The presence of copper (II) oxide nanoparticles (CuONPs) was further confirmed by XRD analysis based on their diffraction peaks (Mathew 2018). Moreover, fresh tea (Camellia sinensis) leaves were applied in a study to reduce non-oxidized metallic CuNPs by using copper (II) chloride $\left(\mathrm{CuCl}_{2}\right)$ salt (Keihan et al. 2016), where $10 \mathrm{ml}$ aqueous extract of fresh tea leaves was inserted drop-wise into $100 \mathrm{ml}$ of $1 \mathrm{mM}$ copper (II) chloride salt solution and the system was refluxed at $100^{\circ} \mathrm{C}$ for $3 \mathrm{~h}$. UV-visible spectra confirmed the development of metallic nanocopper by providing surface plasmon resonance at $560 \mathrm{~nm}$ (Keihan et al. 2016).

Nevertheless, in a comparison with the abovementioned literatures, this study utilized the microwave-heating system at $700 \mathrm{~W}$ with homogenous heating of $160-170^{\circ} \mathrm{C}$ just for 15 minutes for CuNPs synthesis, which was an expeditious, facile and time saving approach for creating non-oxidized metallic CuNPs. Moreover, copper (II) sulfate pentahydrate $\left(\mathrm{CuSO}_{4} .5 \mathrm{H}_{2} \mathrm{O}\right)$ crystal salt was utilized for supplying $\mathrm{Cu}^{2+}$ ions into the synthesizing medium, which is more economic since crystal copper (II) sulfate pentahydrate salt is comparatively cheaper than copper (II) chloride $\left(\mathrm{CuCl}_{2}\right)$ salt. Therefore, this protocol can also produce cheaper metallic CuNPs, and can be more profitable and convenient compared to other methods. In addition, different nanomaterials especially the metallic NPs themselves can often be toxic which produces risk to human body or other mammal cells because of their remarkable chemical, physical and biochemical properties (Dizaj et al. 2014, Phull et al. 2016). However, the result of this study presents non-toxic NP which can be more novel and risk free for evaluating their potentiality particularly in medical and beverage applications.

\section{Conclusion}

Unlike the synthesis of Copper (II) oxide nanoparticles (CuONPs), this study has been a successful protocol of microwave-assisted synthesis of non-oxidized metallic copper nanoparticles (CuNPs) by using green tea (Camellia sinensis) extract. Besides, compared to previously applied methods, the protocol establishes a faster, facile and more time saving approach for creating metallic copper nanoparticles. Synthesized CuNPs obtained in this process also showed excellent stability 
without any aggregation for several months. Moreover, non-toxic nature of these synthesized CuNPs on healthy mouse cells, which further signify their potential in a broad range applications including agriculture, medical and biological research.

\section{Acknowledgement}

This study was produced as part of the $\mathrm{PhD}$ dissertation of the first author. The authors would like to

\section{References}

1. Annamalai, N., Thavasi R., Vijayalakshmi S. \& Balasubramanian, T. 2011. A novel thermostable and halostable carboxymethylcellulase from marine bacterium Bacillus licheniformis AU0. World Journal of Microbiology and Biotechnology, 27: 2111-2115. https://doi.org/10.1007/s11274-011-0674-x

2. Aziz, S.B. 2017. Morphological and optical characteristics of chitosan (1-x): Cuox $(4 \leq \mathrm{x} \leq 12)$ based polymer nanocomposites: optical dielectric loss as an alternative method for Tauc's model. Nanomaterials (Basel), 7(12): 444. https://doi.org/10.3390/nano7120444

3. Cheng, X., Zhang, X., Yin, H., Wang, A. \& Xu, Y. 2006. Modifier effects on chemical reduction synthesis of nanostructured copper. Applied Surface Science, 253(5): 727-2732.

4. Dang, T.M.D., Le, T.T.T., Fribourg-Blanc, E. \& Dang, M.C. 2011. Synthesis and optical properties of copper nanoparticles prepared by a chemical reduction method. Advances in Natural Sciences: Nanoscience and Nanotechnology, 2(1): 015009. https://doi.org/10.1088/2043-6262/2/1/015009

5. Dizaj, S.M., Lotfipour, F., Barzegar-Jalali, M., Zarrintan, M.H. \& Adibkia, K., 2014. Antimicrobial activity of the metals and metal oxide nanoparticles. Materials Science and Engineering: $\quad C, \quad 44: \quad 278-284$. https://doi.org/10.1016/j.msec.2014.08.031

6. Edison, T.J.I. \& Sethuraman, M.G. 2012. Instant green synthesis of silver nanoparticles using Terminalia chebula fruit extract and evaluation of their catalytic activity on reduction of methylene blue. Process Biochemistry, 47: 1351-1357. https://doi.org/10.1016/j.procbio.2012.04.025

7. Gottimukkala, K.S.V., Reddy, H.P. \& Zamare, D. 2017. Green synthesis of iron nanoparticles using green tea leaves extract. Journal of Nanomedicine \& Biotherapeutic Discovery, 7: 151. https://doi.org/10.4172/2155983X.1000151

8. Hassanien, R., Husein, D.Z. \& Al-Hakkani, M.F. 2018. Biosynthesis of copper nanoparticles using aqueous Tilia extract: antimicrobial and anticancer activities. Heliyon, 4(2018): https://doi.org/10.1016/j.heliyon.2018.e01077

9. Irshad, S., Salamat, A., Anjum, A.A., Sana, S., Saleem, R.S.Z., Naheed, A. \& Iqbal, A. 2018. Green tea leaves mediated $\mathrm{ZnO}$ nanoparticles and its antimicrobial activity. Cogent Chemistry, 4(1): 1469207. https://doi.org/10.1080/23312009.2018.1469207

10. Jahan, I., Erci, F. \& Isildak, I. 2019. Microwave-assisted green synthesis of non-cytotoxic silver nanoparticles using convey their heartfelt gratitude to all the lab members of the Polymeric Biomaterials and Macromolecular Synthesis laboratory at Y1ldiz Technical University for their valuable support and assistance. The authors also present special gratefulness to Dr. Fatih Erci and Dr. Rabia ÇAKIR KOÇ for their foresight and immense support.

the aqueous extract of Rosa santana (rose) petals and their antimicrobial activity. Analytical Letters, 52(12): 18601873. https://doi.org/10.1080/00032719.2019.1572179

11. Jha, A.K., Prasad, K. \& Kulkarni, A.R. 2009. Plant system: nature's nano-factory. Colloids Surf B. Biointerfaces, 73(2): 219-223. https://doi.org/10.1016/j.colsurfb.2009.05.018

12. Joseph, S. \& Mathew, B. 2015. Microwave assisted facile green synthesis of silver and gold nanocatalysts using the leaf extract of Aerva lanata. Spectrochimica Acta Part A: Molecular and Biomolecular Spectroscopy, 136: 13711379. https://doi.org/10.1016/j.saa.2014.10.023

13. Kaviya, S., Santhanalakshmi, J., Viswanathan, B., Muthumar, J. \& Srinivasan, K. 2011. Biosynthesis of silver nanoparticles using Citrus sinensis peel extract and its antibacterial activity. Spectrochimica Acta Part A: Molecular and Biomolecular Spectroscopy, 79(3): 594598. https://doi.org/10.1016/j.saa.2011.03.040

14. Keihan, A.H., Veisi, H. \& Veasi H. 2016. Green synthesis and characterization of spherical copper nanoparticles as organometallic antibacterial agent. Applied Organometallic Chemistry, 31(7): e3642. https://doi.org/10.1002/aoc.3642

15. Lee, H., Song, J.Y. \& Kim, B.S. 2013. Biological synthesis of copper nanoparticles using Magnolia kobus leaf extract and their antibacterial activity. Journal of Chemical Technology \& Biotechnology, 88: 1971-1977. https://doi.org/10.1002/jctb.4052

16. López-García, J., Lehocký, M., Humpolíček, P. \& Sáha, P. 2014. HaCaT keratinocytes response on antimicrobial atelocollagen substrates: extent of cytotoxicity, cell viability and proliferation. Journal of Functional Biomaterials, 5(2): 43-57. https://doi.org/10.3390/jfb5020043

17. Lourenço, I.M., Pieretti, J.C., Nascimento, M.H.M., Lombello, C.B. \& Seabra, A.B. 2019. Eco-friendly synthesis of iron nanoparticles by green tea extract and cytotoxicity effects on tumoral and non-tumoral cell lines. Energy, Ecology and Environment, 4: 261-270. https://doi.org/10.1007/s40974-019-00134-5

18. Mathew, A. 2018. Green synthesis of $\mathrm{CuO}$ nanoparticles using tea extract. International Journal for Research in Applied Science \& Engineering Technology, 6(IV): $3457-$ 3458. https://doi.org/10.22214/ijraset.2018.4573

19. Nasrollahzadeh, M. \& Sajadi, S.M. 2015. Green synthesis of copper nanoparticles using Ginkgo biloba L. leaf extract and their catalytic activity for the Huisgen [3+2] cycloaddition of azides and alkynes at room temperature. 
Journal of Colloid and Interface Science, 457: 141-147. https://doi.org/10.1016/j.jcis.2015.07.004

20. Otte, H.M. 1961. Lattice parameter determinations with an $\mathrm{x}$-ray spectrogoniometer by the debye-scherrer method and the effect of specimen condition. Journal of Applied Physics, 32: 1536-1546. https://doi.org/10.1063/1.1728392

21. Phull, A.-R., Abbas, Q., Ali, A., Raza, H., Kim, S.J., Zia, M. \& Haq I.-ul. 2016. Antioxidant, cytotoxic and antimicrobial activities of green synthesized silver nanoparticles from crude extract of Bergenia ciliata. Future Journal of Pharmaceutical Sciences, 2(1): 31-36. https://doi.org/10.1016/j.fjps.2016.03.001

22. Reto, M., Figueira, M.E., Filipe, H.M. \& Almeida, C.M. 2007. Chemical composition of green tea (Camellia sinensis) infusions commercialized in Portugal. Plant Foods for Human Nutrition, 62(4): 139-44. https://doi.org/10.1007/s11130-007-0054-8

23. Rolim, W.R., Pelegrino, M.T., de Araújo Lima, B., Ferraz, L.S., Costa, F.N., Bernardes, J.S., Rodigues, T., Brocchi, M. \& Seabra, A.B. 2019. Green tea extract mediated biogenic synthesis of silver nanoparticles: Characterization, cytotoxicity evaluation and antibacterial activity. Applied Surface Science, 463: 66-74. https://doi.org/10.1016/j.apsusc.2018.08.203

24. Ruparelia, J.P., Chatterjee, A.K., Duttagupta, S.P. \& Mukherji, S. 2008. Strain specificity in antimicrobial activity of silver and copper nanoparticles. Acta Biomater, 4(3): 707-716. https://doi.org/10.1016/j.actbio.2007.11.006

25. Sahu, D., Kannan, G.M., Tailang, M. \& Vijayaraghavan, R. 2016. In-vitro cytotoxicity of nanoparticles: a comparison between particle size and cell type. Journal of Nanoscience, 2016: 1-9. https://doi.org/10.1155/2016/4023852

26. Sreeju, N., Rufus, A. \& Philip, D. 2016. Microwaveassisted rapid synthesis of copper nanoparticles with exceptional stability and their multifaceted applications.
Journal of Molecular Liquids, 221: 1008-1021. https://doi.org/10.1016/j.molliq.2016.06.08

27. Suresh, Y., Annapurna, S., Bhikshamaiah, G. \& Singh, A.K. 2014. Copper nanoparticles: green synthesis and characterization. International Journal of Scientific \& Engineering Research, 5(3): 156-160.

28. Sutradhar, P., Saha, M. \& Maiti, D. 2014. Microwave synthesis of copper oxide nanoparticles using tea leaf and coffee powder extracts and its antibacterial activity. Journal of Nanostructure in Chemistry, 4: 86. https://doi.org/10.1007/s40097-014-0086-1

29. Tanghatari, M., Sarband, Z.N., Rezaee, S. \& Larijani, K. 2017. Microwave assisted green synthesis of copper nanoparticles. Bulgarian Chemical Communications, Special Issue J: 347-352.

30. Tsuji, M., Hashimoto, M., Nishizawa, Y., Kubokawa, M. \& Tsuji, T. 2005. Microwave-assisted synthesis of metallic nanostructures in solution, Chemistry, 11(2): 440-452. https://doi.org/10.1002/chem.200400417

31. Usha, S., Ramappa, K.T., Hiregoudar, S., Vasanthkumar, G.D. \& Aswathanarayana, D.S. 2017. Biosynthesis and characterization of copper nanoparticles from tulasi (Ocimum sanctum L.) leaves. International Journal of Current Microbiology and Applied Sciences, 6(11): 22192228. https://doi.org/10.20546/ijcmas.2017.611.263

32. Wei, Y., Chen, S., Kowalczyk, B., Huda, S., Gray, T.P. \& Grzybowski, B.A. 2010. Synthesis of stable, low-dispersity copper nanoparticles and nanorods and their antifungal and catalytic properties. Journal of Physical Chemistry C, 114(37): 15612-15616. https://doi.org/10.1021/jp1055683

33. Yallappa, S., Manjanna, J., Sindhe, M.A., Satyanarayan, N.D., Pramod, S.N. \& Nagaraja, K. 2013. Microwave assisted rapid synthesis and biological evaluation of stable copper nanoparticles using $T$. arjuna bark extract. Spectrochimica Acta Part A: Molecular and Biomolecular Spectroscopy, 110: 108-115. https://doi.org/10.1016/j.saa.2013.03.005 